\title{
PENGARUH INOKULAN BAKTERI ASAM LAKTAT DAN ADITIF TERHADAP KUALITAS DAN KARAKTERISTIK SILASE SORGUM MUTAN BROWN MIDRIB (Sorghum bicolor L. Moench)
}

\author{
R. Sriagtula ${ }^{1}$, I. Martaguri ${ }^{1}$, J. Hellyward ${ }^{2}$, S. Sowmen ${ }^{1}$ \\ ${ }^{1}$ Bagian Nutrisi dan Teknologi Pakan, Fakultas Peternakan Universitas Andalas, Padang \\ ${ }^{2}$ Bagian Pembangunan Bisnis Peternakan Fakultas Peternakan Universitas Andalas, Padang \\ Email: riesiteguh@gmail.com
}

\begin{abstract}
ABSTRAK
Penelitian ini bertujuan untuk mengobservasi pengaruh penambahan inokulasi bakteri asam laktat (BAL) dan aditif terhadap kualitas dan karakterietik silase whole crop sorgum mutan brown midrib (Sorghum bicolor L. Moench) galur Patir 3.7 yang dipanen pada fase soft dough. Penelitian dilaksanakan secara eksperimen menggunakan rancangan acak lengkap pola faktorial dengan 4 ulangan. Faktor A yaitu A1 = tanpa BAL, A2= penambahan BAL. Faktor B terdiri dari B1= tanpa aditif, B2= dedak, B3= jagung. Sumber BAL yang digunakan berasal dari inokulan komersil dari minuman fermentasi merk Yakult dengan dosis $1 \mathrm{ml}(\mathrm{v} / \mathrm{w})$ atau $11 \times 10^{9} \mathrm{CFU} / \mathrm{ml} /$ berat segar. Aditif terdiri dari dedak padi dan jagung halus digunakan sebanyak $3 \%(\mathrm{~g} / \mathrm{g}) /$ berat segar. Parameter yang diamati adalah karakteristik dan kualitas silase meliputi nilai $\mathrm{pH}$, nilai fleigh (NF), kandungan bahan kering (BK), protein kasar (PK), serat kasar (SK), lemak kasar (LK) dan Abu. Data dianalisis berdasarkan analisis keragaman menurut Duncan Multiple Range Test (DMRT). Hasil penelitian menunjukkan bahwa tidak terdapat interaksi $(\mathrm{P}>0,05)$ antara penambahan $\mathrm{BAL}$ dan aditif terhadap $\mathrm{pH}, \mathrm{NF}, \mathrm{BK}, \mathrm{PK}, \mathrm{SK}, \mathrm{LK}$ dan abu, sedangkan faktor tunggal adititif memberikan pengaruh berbeda nyata $(\mathrm{P}<\mathrm{O}, 05)$ lebih tinggi terhadap kandungan BK silase whole crop sorgum mutan BMR. Dari penelitian ini dapat disimpulkan bahwa secara umum penambahan inokulan BAL dan aditif menghasilkan karakteristik dan kualitas silase yang sama, namun demikian penambahan dedak padi dan jagung halus menghasilkan BK silase yang lebih tinggi dibanding tanpa BAL dan aditif.
\end{abstract}

Kata kunci: aditif, BAL, brown midrib, silase, sorgum

\section{PENDAHULUAN}

Hijauan pakan merupakan menu utama ternak ruminansia dengan tingkat konsumsi yang tinggi mencapai $70 \%$ dari total ransum (Abdullah, 2014). Hijauan harus dipertahankan dalam ransum ruminansia karena biaya produksi untuk hijauan lebih rendah dibanding konsentrat dan lebih ramah lingkungan sehingga lebih cocok untuk pengembangan industri ternak berkelanjutan. Keberadaan hijauan dalam ransum membantu menjaga fungsi rumen berjalan dengan baik, mengurangi resiko asidosis, dan meningkatkan konsumsi (Sari et al., 2015). Namun, ketersediaan hijauan berkelanjutan masih menjadi kendala terutama dipengaruhi oleh faktor musim. Pada musim penghujan produksi hijauan tinggi, sebaliknya pada musim kemarau hijauan tidak dapat tumbuh dengan baik sehingga terjadinya fluktuasi produksi (Siregar, 1994).

Upaya untuk menghindari fluktuasi hijauan pakan dapat dilakukan dengan pengawetan hijauan pada saat produksinya melimpah yaitu dengan menerapkan teknologi fermentasi (Diwyanto dan Inounu, 2001). Salah satu usaha dalam penerapan teknologi fermentasi adalah melalui proses ensilase untuk menghasilkan silase. Silase merupakan salah satu teknik pengawetan pakan atau hijauan pada kadar air tertentu melalui proses fermentasi mikrobial oleh bakteri yang berlangsung di dalam tempat yang disebut silo (McDonald et al. 2002).

Silase merupakan teknik pengawetan yang paling efektif untuk suplai pakan ternak pada musim kering di daerah tropis. Namun, silase yang berkualitas tinggi di daerah tropis sulit dihasilkan karena rendahnya bakteri asam laktat (BAL) dan karbohidrat yang larut dalam air (WSC) pada hijauan tropis (Pholsen et al., 2016). Upaya untuk meningkatkan kualitas silase hijauan tropis adalah dengan penggunaan aditif pada proses ensilase yang dapat menstimulasi fermentasi bakteri asam laktat (BAL) (Bureenok et al. 2006). Selain itu, umumnya hijauan di daerah tropis memiliki kandungan air yang cukup tinggi $(>80 \%)$ yang menyebabkan asam butirat menjadi produk fermentasi utama sehingga proses ensilase tidak berhasil (Pholsen, 2016). Untuk itu perlu dilakukan pelayuan dan penambahan zat aditif dan BAL dalam proses ensilase. Hartadi et al. (2005) menyatakan penambahan aditif seperti dedak padi yang memiliki 
kandungan karbohidrat yang mudah tersedia cukup tinggi yaitu bahan ekstrak tanpa nitrogen (BETN) $48,7 \%$, dapat mempertahankan kualitas hijauan. Ridwan et al. (2005) melaporkan bahwa penambahan dedak padi $1-5 \%$ pada pembuatan silase rumput gajah berpengaruh terhadap peningkatan kualitas silase.

Tanaman sorgum (Sorghum bicolor L. Moench) sering dijadikan silase karena produksi bahan kering yang tinggi dan toleran kekeringan. Tanaman sorgum merupakan tanaman sereal yang dapat menghasilkan biji dan gula pada batang, disamping menghasilkan hijauan. Silase sorgum dalam bentuk whole plant (batang, daun, malai) menghasilkan kualitas yang lebih rendah disbanding silase tebon jagung (maize stover), karena sorgum yang digunakan merupakan varietas konvensional yang mengandung lignin lebih tinggi (8\%) (Miller and Stroup, 2003), sehingga mempengaruhi kinerja bakteri dalam proses ensilase. Sorgum brown midrib (BMR) merupakan hasil mutasi dengan kandungan lignin yang lebih rendah (6\%) dan kandungan brix gula pada batang rata rata $13,37 \%$ (Sriagtula et al., 2016). Biji sorgum kaya akan pati dan gula pada batang, merupakan karbohidrat mudah tersedia sebagai sumber energi bagi bakteri asam laktat dalam proses ensilase, sehingga penambahan zat aditif dalam bentuk karbohidrat mudah terfermentasi mungkin menjadi tidak penting dalam proses ensilase whole plant (tebon) sorgum mutan BMR. Sorgum untuk dijadikan silase sebaiknya dipanen pada fase soft dough (Gerik et al., 2003). Berdasarkan pemikiran di atas dilakukanlah penelitian yang bertujuan mengobservasi pengaruh penambahan BAL dan aditif berbeda terhadap kualitas nutrisi silase sorgum mutan BMR.

\section{MATERI DAN METODA}

\section{Materi}

Penelitian menggunakan whole plant (batang, daun dan malai) galur sorgum mutan BMR Patir 3.7 (Sorghum bicolor L. Moench ), dedak padi, jagung, dan Yakult. Peralatan yang digunakan adalah kantong plastik, gunting stek, mesin chopper, timbangan, vakum danoven.

\section{Metode}

Penelitian dilaksanakan secara eksperimen menggunakan rancangan acak lengkap pola faktorial dengan 4 ulangan. Faktor A terdiri dari $\mathrm{A} 1$ = tanpa $\mathrm{BAL}, \mathrm{A} 2$ = penambahan BAL. Faktor $\mathrm{B}$ terdiri dari B1 = tanpa aditif, B2 = dedak padi, B3 $=$ jagung halus. Sehingga terdapat 24 kombinasi perlakuan. Sumber BAL yang digunakan dalam penelitian ini berasal dari minuman fermentasi merk Yakult dengan dosis $1 \mathrm{ml}(\mathrm{v} / \mathrm{w}) /$ berat segar (Pholsen et al., 2016) dengan populasi $11 \times 10^{9} \mathrm{CFU} /$ $\mathrm{ml}$, sedangkan dedak padi dan jagung digunakan sebanyak $3 \%(\mathrm{~g} / \mathrm{g}) /$ berat segar (Ridwan et al. 2005).

\section{Prosedur Pembuatan Silase}

Tanaman galur sorgum mutan BMR Patir 3.7 dipanen pada fase soft dough (9o hari setelah tanam/ HST), kemudian dipotong menggunakan mesin chopper. Bahan kemudian dilayukan selama semalam agar kandungan airnya berkurang. Penambahan BAL dan aditif dilakukan sesuai perlakuan dengan cara mencampur rata antara BAL, aditif dan hijauan. Setelah tercampur rata kemudian dimasukkan ke dalam kantong plastik (silo) sambil dipadatkan menggunakan pompa vakum agar hampa udara. Kantong diikat rapat dan disimpan selama 21 hari, kemudian dipanen dan dilakukan pengujian kualitas dan karakteristik silase meliputi nilai $\mathrm{pH}$, nilai fleigh (NF), bahan kering (BK), protein kasar (PK), serat kasar (SK), lemak kasar (LK), dan abu.

\section{Prosedur Pengukuran Peubah}

1. Kandungan nutrisi

Kualitas nutrisi silase diamati dengan analisis proksimat menggunakan metode AOAC (1980).

2. Nila $\mathrm{pH}$

Sebanyak $10 \mathrm{~g}$ sampel silase direndam dengan aquadest sebanyak $50 \mathrm{ml}$. Setelah itu diaduk dan diamkan selama 15 menit, nilai $\mathrm{pH}$ diukur menggunakan $\mathrm{pH}$ meter.

\section{Analisis Data}

Data dianalisis menggunakan sidik ragam (ANOVA). Apabila terdapat perbedaan yang nyata antar perlakuan, maka dilanjutkan dengan uji Duncan Multiple Range Test (DMRT) menurut Steel and Torri (1997).

\section{HASIL DAN PEMBAHASAN}

Pengaruh perlakuan terhadap kandungan nutrisi disajikan pada Tabel 1. Hasil penelitian menunjukkan bahwa tidak terdapat interaksi $(\mathrm{P}>0,05)$ antara inokulasi BAL dan aditif terhadap kandungan nutrisi (BK, PK, SK, LK dan abu) silase sorgum mutan BMR Patir 3.7. Pengaruh faktor tunggal inokulasi BAL dan aditif memberikan pengaruh berbeda nyata $(\mathrm{P}<0,05)$ hanya pada kandungan $\mathrm{BK}$. Pada penelitian ini kandungan BK nyata lebih tinggi pada perlakuan yang mendapat penambahan dedak padi (B2) dan jagung halus (B3). Lebih tinggi kandungan BK pada perlakuan B2 dan B3 karena bahan pada perlakuan tersebut ditambahkan aditif dedak padi dan jagung 
Tabel 1. Kandungan nutrisi silase galur sorgum mutan BMR Patir 3.7

\begin{tabular}{lccccc}
\hline \multicolumn{1}{c}{ Parameter } & & B1 & B2 & B3 & Rataan \\
\hline Bahan & A1 & $21,99 \pm 0,78$ & $23,69 \pm 1,12$ & $22,95 \pm 0,55$ & $22,88 \pm 1,06$ \\
kering (\%) & A2 & $22,57 \pm 0,53$ & $23,79 \pm 1,34$ & $23,97 \pm 1,20$ & $23,49 \pm 1,16$ \\
& Rataan & $22,24 \pm 0,71^{\mathrm{b}}$ & $23,73 \pm 1,11^{\mathrm{a}}$ & $23,46 \pm 1,02^{\mathrm{a}}$ & \\
Protein & A1 & $7,91 \pm 1,19$ & $7,96 \pm 1,22$ & $8,98 \pm 1,38$ & $8,29 \pm 1,22$ \\
kasar (\%) & A2 & $8,52 \pm 2,93$ & $11,21 \pm 0,59$ & $8,15 \pm 1,60$ & $9,36 \pm 2,18$ \\
& Rataan & $8,27 \pm 2,18$ & $9,58 \pm 1,95$ & $8,51 \pm 1,45$ & \\
Serat kasar & A1 & $30,07 \pm 0,58$ & $28,46 \pm 2,31$ & $29,78 \pm 1,72$ & $29,44 \pm 1,70$ \\
& A2 & $26,26 \pm 2,37$ & $29,07 \pm 1,85$ & $28,12 \pm 1,32$ & $28,13 \pm 1,88$ \\
Lemak & Rataan & $28,80 \pm 2,28$ & $28,76 \pm 1,97$ & $28,95 \pm 1,68$ & \\
kasar (\%) & A1 & $3,99 \pm 0,89$ & $4,82 \pm 1,45$ & $5,17 \pm 0,58$ & $4,66 \pm 1,07$ \\
\hline \hline & A2 & $3,04 \pm 0,88$ & $3,84 \pm 0,47$ & $4,57 \pm 1,14$ & $3,97 \pm 0,98$ \\
Abu (\%) & Rataan & $3,68 \pm 0,94$ & $4,33 \pm 1,13$ & $4,87 \pm 0,89$ & \\
& A1 & $6,70 \pm 1,47$ & $5,36 \pm 3,48$ & $8,33 \pm 0,78$ & $6,79 \pm 2,38$ \\
& A2 & $3,53 \pm 2,14$ & $5,16 \pm 3,02$ & $6,02 \pm 3,93$ & $5,19 \pm 3,12$ \\
\hline
\end{tabular}

Keterangan : Angka yang diikuti huruf kecil pada baris dan kolom yang sama menunjukkan pengaruh yang berbeda nyata $(P<0,05)$. $A 1=\operatorname{tanpa} B A L, A 2=B A L, B 1=\operatorname{tanpa}$ aditif, $\mathrm{B} 2=$ dedak, $\mathrm{B} 3=$ jagung halus

halus sehingga terjadi penambahan BK pada bahan.

Tidak berbeda nyata $(\mathrm{P}>0,05)$ faktor tunggal BAL dengan aditif terhadap kandungan nutrisi, disebabkan kandungan fermentable sugar pada penelitian ini cukup tinggi. Kandungan gula pada batang sorgum mutan BMR Patir 3.7 adalah 13\% (Sriagtula et al. 2016). Faktor lain yang meyebabkan kandungan nutrisi pada penelitian ini berbeda tidak nyata adalah nilai $\mathrm{pH}$ yang juga berbeda tidak nyata pada penelitian ini. Hal ini sesuai dengan pernyataan McDonald et al. (2002) bahwa $\mathrm{pH}$ yang lebih rendah menghambat degradasi protein dan nutrien lainnya dalam silase, akibatnya kandungan nutrisi pada silase tebon sorgum BMR pada penelitian ini tidak berbeda.

Penambahan aditif berupa dedak padi (B2) dan jagung halus (B3) menghasilkan kualitas silase yang tidak berbeda nyata $(\mathrm{P}>0,05)$, hal ini karena bahan silase adalah whole crop (tebon) sorghum yang terdiri atas batang daun dan malai. Batang sorgum mengandung gula yang tinggi sehingga disebut juga dengan sorgum manis. Malai sorgum pada fase soft dough sudah menghasilkan biji yang merupakan sumber pati. Gula dan pati pada tebon sorgum merupakan karbohidrat yang mudah terfermentasi (fermentable sugar) dan merupakan bagian dari water soluble carbohydrate (WSC). Hal ini meyebabkan penambahan aditif pada penelitian menghasilkan kualitas silase yang sama baik dibanding kontrol. Long et al. (2006) menyatakan bahwa kandungan gula pada batang sorgum merupakan faktor penting untuk menghasilkan silase sorgum berkualitas.

Perlakuan inokulasi BAL menghasilkan kandungan nutrisi dan karakteristik silase yang berbeda tidak ( $\mathrm{P}>0.05$ ) dengan perlakuan tanpa BAL. Hal ini disebabkan bakteri asam laktat alami yang terdapat pada silase tebon sorgum mempunyai aktivitas yang baik karena adanya gula pada bahan. Sriagtula et al. (2016) menyatakan bahwa tebon sorgum BMR Patir 3.7 yang dipanen pada fase soft dough mempunyai kandungan gula batang $13 \%$ Brix. Hal ini didukung oleh pernyataan Jones et al. (2004) gula merupakan makanan utama bakteri asam laktat, kandungan gula yang rendah pada bahan akan menghambat aktivitas bakteri asam laktat. Penambahan BAL pada penelitian ini tidak memberikan pengaruh yang nyata, hal ini sesuai dengan hasil penelitian Koc et al. (2009) bahwa inokulasi LAB Lactobacillus plantarum and Enterococcus faecium pada silase bunga matahari tidak memperbaiki kandungan BK, PK, LK dan abu.

Karakteristik silase dapat ditunjukkan oleh nilai pH dan nilai fleigh (NF) yang disajikan pada Tabel 2. Hasil penelitian menunjukkan tidak terdapat interaksi (P>0,05) antara inokulasi BAL dan aditif terhadap nilai $\mathrm{pH}$ dan NF, begitu juga faktor tunggal inokulasi BAL dan aditif memberikan pengaruh yang berbeda tidak nyata $(\mathrm{P}>0.05)$. Nilai $\mathrm{pH}$ pada penelitian ini berkisar 3,58-3,60, nilai ini tergolong baik. Gunawan et al. (1988) menyatakan bahwa kualitas silase dikategorikan baik jika pH 3,5-4,5.

Tabel 2. Karakteristik silase galur sorgum mutan BMR Patir 3.7

\begin{tabular}{|c|c|c|c|c|c|}
\hline $\begin{array}{c}\text { Para- } \\
\text { me- } \\
\text { ter }\end{array}$ & & B1 & B2 & $\mathrm{B}_{3}$ & Rataan \\
\hline \multirow[t]{4}{*}{$\mathrm{pH}$} & A1 & $3,59 \pm 0,05$ & $3,57 \pm 0,04$ & $3,61 \pm 0,05$ & $3,59 \pm 0,05$ \\
\hline & A2 & $3,56 \pm 0,03$ & $3,61 \pm 0,04$ & $3,60 \pm 0,04$ & $3,59 \pm 0,04$ \\
\hline & Rataan & $3,58 \pm 0,05$ & $3,59 \pm 0,04$ & $3,60 \pm 0,04$ & \\
\hline & A1 & $105,24 \pm 2,81$ & $109,54 \pm 3,66$ & $106,51 \pm 2,11$ & $107,10 \pm 3,25$ \\
\hline \multirow[t]{2}{*}{$\mathrm{NF}$} & A2 & $108,08 \pm 1,25$ & $106,63 \pm 3,67$ & $109,15 \pm 3,09$ & $107,94 \pm 2,92$ \\
\hline & Rataan & $106,46 \pm 2,61$ & $108,09 \pm 3,73$ & $107,83 \pm 2,83$ & \\
\hline
\end{tabular}


Nilai fleigh (NF)merupakan indeks karakteristik fermentasi silase berdasarkan nilai BK dan $\mathrm{pH}$ dari silase. Idikut et al. (2009) menyatakan jika NF berada pada nilai ( $>85$ ) dinyatakan silase yang dihasilkan berkualitas baik sekali, 60 - 80 baik, 40 - 60 cukup baik, 20 - 40 sedang dan kurang baik jika mempunyai $\mathrm{NF}<20$. Pada penelitian ini NF melebihi angka 100, namun nilai fleigh yang melebihi angka 100 juga ditemukan oleh Idikut et al. (2009). Tingginya nilai fleigh disebabkan oleh tingginya BK silase dan rendahnya nilai $\mathrm{pH}$ silase yang dicapai, seperti yang diperlihatkan dari rumus perhitungan $\mathrm{NF}=220+(2 \times \mathrm{BK}(\%)-15)$ $-(40 \times \mathrm{pH})$.

\section{UCAPAN TERIMAKASIH}

Penelitian ini didanai oleh BOPTN Universitas Andalas dalam skim Penelitian Riset Dasar dengan kontrak No. 15/UN.16.17/PP.RD/LPPM/2018.

\section{DAFTAR PUSTAKA}

Abdullah, L. 2014. Peran stategis hijauan pakan. Artikel HITPI. www.hitpi.org.

AOAC. 1980. Official Methods of Analysis. $13^{\text {th }}$ Edition. Association of Official Analytical Chemist, Washington DC.

Bureenok S, Namihira T, Mizumachi S, Kawamoto Y, Nakada T. 2006. The effect of epiphytic lactic acid bacteria with or without different byproduct from defatted rice bran and green tea waste on napiergrass (Pennisetum purpureum Shumach) silage fermentation. J Sci Food Agric. 86:1073-1077. doi: 10.1002/jsfa.2458.

Diwyanto K, I. dan Inounu. 2001. Ketersediaan teknologi dalam pengembangan ruminansia kecil. Institut Pertanian Bogor. hlm 121-130.

Gerik T, Bean B, Vanderlip R. 2003. Sorghum Growth and Development. Texas Cooperative Extension Service.

Gunawan., B. Tangendjaya., D. Zainuddin., J. Darma., A. Thalib. 1988. Laporan Penelitian Silase. Balai Penelitian Ternak, Bogor.

Hartadi H, Reksohadiprojo S, Tilman AD. 2005. Tabel Komposisi Pakan untukIndonesia. Yogyakarta (ID): Gadjah Mada Univ Press.

Idikut, L., B. A. Arikan., M. Kaplan., I. Gaven., A. I. Atalay., A. Kamalak. 2009. Potential nutritive value of sweet corn as a silage crop with or without Corn Ear. Dept. of Animal Science, Faculty of Agriculture. Turkey.

Jones, C.M., A.J. Heinrichs., G.W. Roth., V.A. Ishler. 2004. From Harvest to Feed: Understanding Silage Management. Cooperative Extension, College of Agricultural Sciences. Penn State. Koc. F., M.L. Ozduven, L. Coskuntuna and C. Polat, 2009. The effects of inoculant lactic acid bacteria on the fermentation and aerobic stability of sunflower silage. Poljoprivreda / Agriculture. 15(2):47-52.

Long BY, Seiji Y, Maiko I, Wei CH. 2006. QTLs for sugar content of stalk in sweet sorghum (Sorghum bicolor L. Moench). Agricultural Sciences in China 2006, 5(10): 736-744.

McDonald P, Edwards RA, Greenhalgh JFD, Morgan CA. 2002. AnimalNutrition. $6^{\text {th }}$ Ed. Harlow (GB): Pearson Education.

Miller FR, Stroup JA. 2003. Brown midrib forage sorghum, sudangrass, and corn: What is the potential? Proc. 33rd California Alfalfa and Forage Symposium, pp.143-151.

Pholsen, S., W. Khota, H. Pang, D. Higgs, and Y. Cai. 2016. Charac-terization and application of lactic acid bacteria for tropical silage preparation. Anim. Sci. J. http://dx.doi. org/10.1111/asj.12534.

Ridwan R, Ratnakomala S, Kartina G, Widyastuti Y. 2005. Pengaruh penambahan dedak padi dan Lactobacillus plantarum 1BL-2 dalam pembuatan silase rumput gajah. Med Pet. 28(3):117-123.

Sari, M., A.Ferret., S. Calsamiglia. 2015. Effct of $\mathrm{pH}$ on in vitro microbial fermentation and nutrient flw in diets containing barley straw or non-forage fier sources. Anim. Feed Sci. Tech. 200:17-24. htts://doi.org/10.1016/j. anifeedsci.2014.11.011.

Siregar, S. 1994. Ransum Ternak Ruminansia. Penebar Swadaya. Jakarta.

Sriagtula, R., Karti P. D. M. H., Abdullah, L., Supriyanto, \& Astuti DA. 2016. Dynamics of fiber fraction in generative stage of M10-BMR sorghum mutant lines. International Journal of Sciences: Basic and Applied Research (IJSBAR), Vol 25, No 2, pp 58-69. 